\title{
Glucose-Triggered Release Using Enzyme-Gated Mesoporous Silica Nanoparticles
}

\author{
Elena Aznar, ${ }^{a, b}$ Reynaldo Villalonga, ${ }^{c, d}$ Cristina Giménez, ${ }^{b, a}$ Félix Sancenón, ${ }^{b, e, a}$ M. Dolores Marcos, ${ }^{b, e, a}$ \\ Ramón Martínez-Máñez, ${ }^{* b, e, a}$ Paula Díez, ${ }^{c}$ José M. Pingarrón $^{c, d}$ and Pedro Amorós ${ }^{f}$
}

\begin{abstract}
A new gated nanodevice design able to control cargo delivery using glucose as trigger and cyclodextrin-modified glucose oxidase as capping agent is reported.
\end{abstract}

Mass transport control at the nanometric level is a captivating area of research that has attracted the attention of scientists in the latest years. Especially, the development of gated systems able to retain a cargo and release it after the application of a stimulus has demonstrated to be an excellent approach for the development of smart nanodevices for advanced delivery applications. ${ }^{1}$ In this context, silica mesoporous supports are widely used as inorganic scaffolds thanks to their unique characteristics such as high homogeneous porosity, inertness, robustness, thermal stability, the presence of tunable pore sizes, homogeneous pore distribution and high loading capacity. ${ }^{2}$ Moreover, via decoration of the mesoporous material with a wide collection of organic moieties, linkers and capping agents, researchers have prepared nanovalves that can be triggered with target chemical ${ }^{3}$ (such as redox molecules, selected anions, $\mathrm{pH}$ changes and biomolecules) physical ${ }^{4}$ (such as light, temperature or magnetic fields) and biochemical (such as enzymes, antibodies, or DNA) stimuli. ${ }^{5}$

In particular the development of enzyme-responsive bio-gated mesoporous silica nanoparticles is appealing. In previously reported examples tailor-made sequences anchored on the mesoporous support are hydrolized by target enzymes allowing the selective release of the entrapped cargo. However in these cases enzymes act as triggers but as far as we know there are not examples where enzymes were used as functional gating elements. ${ }^{6}$ In this context, and as a new approach, we envisioned the potential design of gated materials in which the enzymes could act as caps and the uncapping process would be triggered

\footnotetext{
${ }^{a}$ CIBER de Bioingeniería, Biomateriales y Nanomedicina (CIBER-BBN).

${ }^{b}$ Centro de Reconocimiento Molecular y Desarrollo Tecnológico (IDM).

Unidad Mixta Universitat Politècnica de València-Universitat de

València. Valencia, Spain. Fax: (+34) 963879349; E-mail:

rmaez@qim.upv.es

${ }^{c}$ Department of Analytical Chemistry, Faculty of Chemistry, Universidad Complutense de Madrid, 28040, Madrid, Spain

${ }^{d}$ IMDEA Nanoscience, Ciudad Universitaria de Cantoblanco, 28049, Madrid, Spain.

${ }^{e}$ Departamento de Química. Universitat Politècnica de València. Camino de Vera s/n, 46022, Valencia, Spain.

${ }^{f}$ Institut de Ciència del Materials (ICMUV). Universitat de València. P.O. Box 2085, 46071Valencia.

† Electronic Supplementary Information (ESI) available: [Experimental details. S1 and S2 characterization.]. See DOI: 10.1039/b000000x/
}

by the product obtained by the enzyme's activity on a target substrate. The combination of the promising features of silica mesoporous supports as containers, enzymes as caps and substrates as trigger would result in a sophisticated but simple way to prepare selective substrate-responsive gated mesoporous materials for different applications. As a proof-of-concept we have selected herein glucose oxidase as capping enzyme and glucose as the substrate to trigger cargo release.

The designed capped support is depicted in Scheme 1. It is based on the use of mesoporous silica nanoparticles loaded with a suitable reporter (i.e. ruthenium bipyridine complex) and containing anchored methylbenzymidazole moieties on the pore outlets. The mesopores are then capped with an active CDmodified-glucose oxidase (CD-GOx) through the formation of an inclusion complex between the cyclodextrins and the propylbenzymidazole group anchored to the solid support. The presence of the substrate glucose combined with the catalytic action of CD-GOx to produce gluconic acid was expected to induce protonation of the benzymidazole group that might result in the inclusion complex dethreating and the subsequent cargo release.

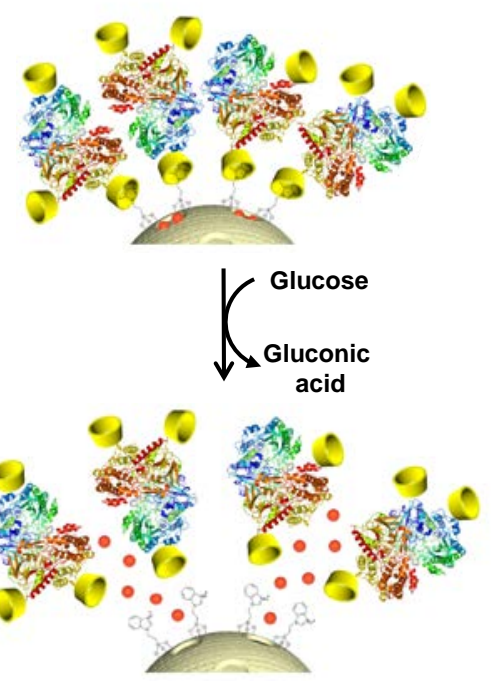

Scheme 1. Solid S3 expected performance.

In this context, to the best of our knowledge, the use of glucose as trigger for a gated system has only been described by Lin et. al.. 
In their work, they reported a saccharide-responsive controlled release of insulin and cAMP using phenylboronic acidfunctionalized silica mesoporous nanoparticles. ${ }^{6}$ However, this later system was based in a simple displacement reaction yet no enzymes were used in its design.

In order to prepare the gated nanodevice, silica mesoporous (MCM-41-type) nanoparticles (ca. 100-150 nm) were selected as inorganic scaffold. The MCM-41 support was loaded with a suitable dye $\left(\left[\mathrm{Ru}(\mathrm{bpy})_{3}\right] \mathrm{Cl}_{2}\right)$ and the external surface was functionalized with 3-iodopropyltrimethoxysilane (solid S1). Then, a nucleophilic substitution reaction of the anchored 3iodopropyl moiety with benzimidazole resulted in a solid functionalised with 1-propyl-1-H-benzimidazole groups (solid S2).

These intermediate supports (S1 and S2) were characterized using standard procedures (see Supporting Information). X-ray diffraction pattern of S2 (Figure 1) shows the mesoporous characteristic (100) diffraction peak indicating that the loading process with the dye and the further functionalization to obtain the benzimidazole domains have not modified the structure of the mesoporous scaffolding. Moreover, contents of $0.48 \mathrm{mmol} \mathrm{g}^{-1}$ $\mathrm{SiO}_{2}$ of dye and $0.54 \mathrm{mmol} \mathrm{g}^{-1} \mathrm{SiO}_{2}$ of benzimidazole on solid S2 were determined by elemental analysis and thermogravimetric studies.
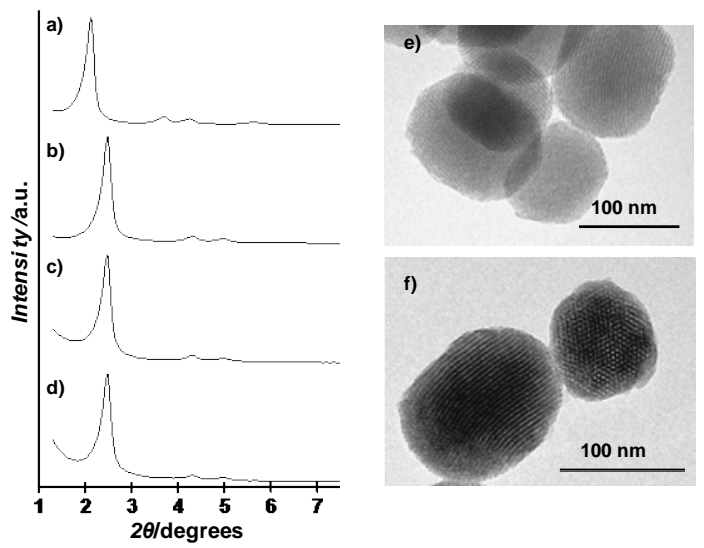

Figure 1. Powder X-ray diffraction pattern of a) MCM-41 as made, b) calcined MCM-41, c) solid S1 and d) solid S2 showing the typical reflections of the MCM-41 hexagonal array. TEM representative images of e) calcined MCM-41 and f) solid S2 showing the typical porosity of the MCM-41 mesoporous matrix.

For the preparation of the final gated material, CD-GOx was synthesized as previously reported ${ }^{7}$ and a mixture of $\mathbf{S} 2$ and CD$\mathrm{GOx}$ in water at $\mathrm{pH} 7.5$ was stirred for $24 \mathrm{~h}$. After that time, the capped solid was centrifuged and washed with water at $\mathrm{pH} 7.5$ three times to obtain the orange final solid S3. (see Supporting Information for further details)

In order to test the gating properties of the solid, portions of $150 \mu \mathrm{L}$ of a suspension of $\mathbf{S} 3\left(6.7 \mathrm{mg} \mathrm{mL}^{-1}\right)$ were diluted with 3 $\mathrm{mL}$ of water at $\mathrm{pH} 7.5$ in the presence of glucose $\left(0.1 \mathrm{molL}^{-1}\right)$ and stirred for a certain time. As a control experiment another portion of $150 \mu \mathrm{L}$ of the suspension of S3 was diluted in the same proportion and stirred. During the experiments, at a given time, $0.3 \mathrm{~mL}$ of each suspension was filtered, and the absorbance at $453 \mathrm{~nm}$ of the released $\left[\mathrm{Ru}(\mathrm{bpy})_{3}\right] \mathrm{Cl}_{2}$ was measured.

The delivery kinetics profile of the ruthenium dye in the presence and absence of glucose is shown in Figure 2. In absence of glucose (curve a) solid S3 shows a very poor dye release, indicating tight pore closure. On the other hand, the delivery of the dye is induced when glucose is present in the solution (curve b) due to displacement of the CD-GOx as consequence of CDGOx-induced oxidation of glucose to gluconic acid and protonation of the benzimidazole group. Thus, the presence of glucose allows the release of 51\% of the entrapped dye. Additionally, the figure also shows how release from the capped system can be triggered on command by adding glucose at a certain time (curve c).

The obtained results confirmed the triggering event hypothesis; i.e. whereas solid S3 displayed no release, the presence of the substrate of the enzyme acting as cap induced the delivery of the entrapped guest. Moreover, to confirm that the opening protocol was due to protonation of the benzimidazole which induced the dethreating of the inclusion complex, $\mathrm{pH}$ changes in the final aliquots were measured. Thus, only in the experiments in which glucose was present a change from $\mathrm{pH} 7.5$ to $\mathrm{pH}<5.2$ was observed confirming the enzyme-mediated conversion of glucose in gluconic acid.

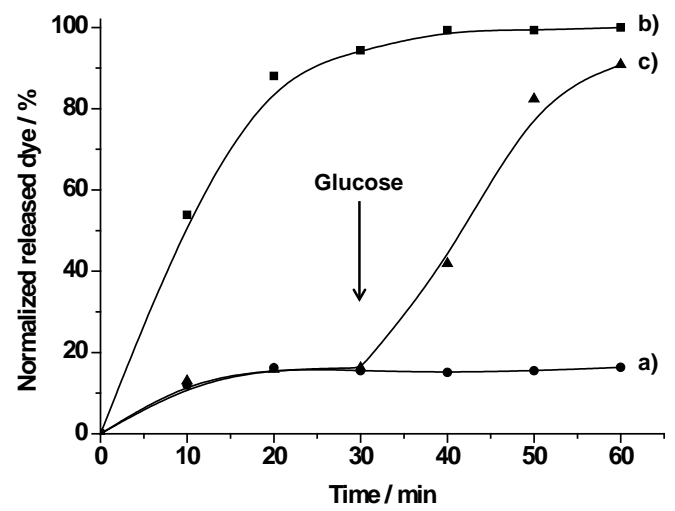

Figure 2. Release profile of $\left[\mathrm{Ru}(\mathrm{bpy})_{3}\right] \mathrm{Cl}_{2}$ from solid $\mathbf{S} 3$ at $\mathrm{pH} 7.5$ a) in the absence of glucose, b) in the presence of glucose c) with glucose addition at $30 \mathrm{~min}$.

On the other hand, we believe that solid S3 or similar systems could be of application in the development of glucose-induced delivery systems or in the design of colorimetric probes for glucose determination. In this context, and as a further step in the characterization of the delivery system, the response of the hybrid material S3 as a function of the glucose concentration was studied and the results are illustrated in Figure 3. From these data a linear release of the dye from S3 in the $1 \times 10^{-2}-1 \times 10^{-4} \mathrm{molL}^{-1}$ glucose concentration range was found. Moreover a detection limit of glucose of $1.5 \times 10^{-4} \mathrm{molL}^{-1}$ was calculated which was in the range of other glucose-responsive reported detection systems. ${ }^{8}$ Taking into account that the general range of blood glucose concentration in healthy and diabetic humans is about 3-8 $\mathrm{mM}$ and 9-40 mM, respectively, ${ }^{9}$ we can envision the potential of this enzyme-gated systems for the design of chromo-fluorogenic probes for glucose detection.

Figure 3. Released dye from solid S3 in the presence of different glucose concentrations. 


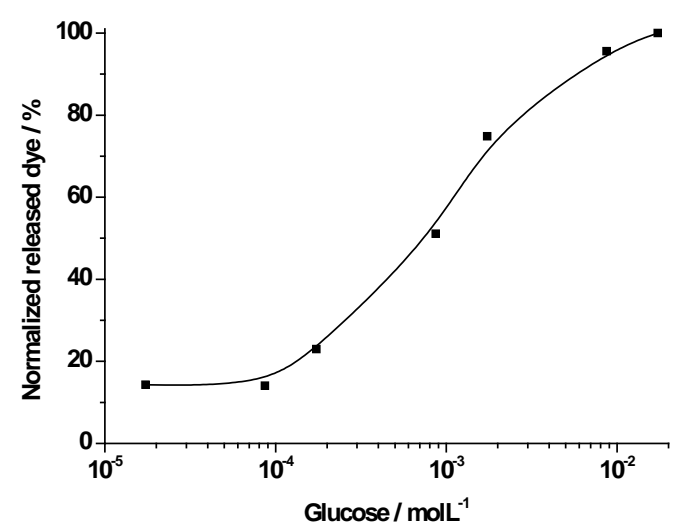

Moreover, as it is well-known enzymes are selective catalytic centres. In our case, although numerous sugars and derivatives of glucose have been reported to be substrates of GOx, the enzyme shows far greater activity with glucose. In this scenario, the selectivity in the opening protocol in S3 was tested in the presence of different saccharides such as mannose, fructose, galactose, maltose and saccharose at a concentration of $1 \times 10^{-3}$ $\mathrm{molL}^{-1}$ and following the same described procedure. As it can be seen in Figure 4 a selective uncapping was observed in the

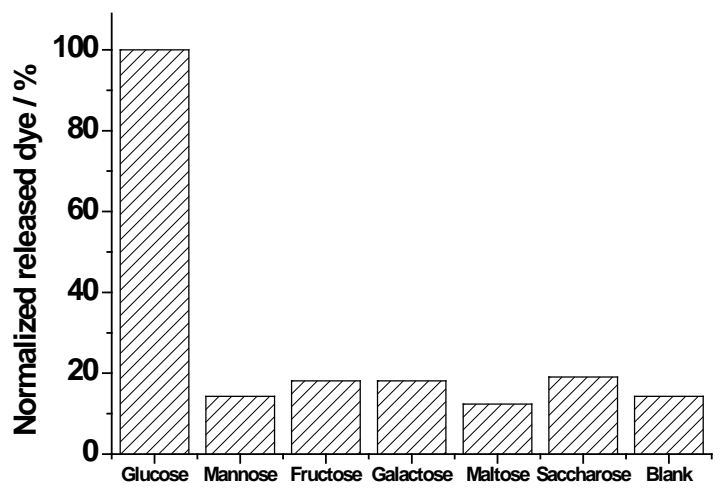

presence of glucose confirming the selective triggering.

Figure 4. Released dye from $1 \mathrm{mg}$ of solid $\mathbf{S 3}$ in the presence of different analytes $\left(1 \times 10^{-3} \mathrm{molL}^{-1}\right)$.

In summary, we have reported a new approach for the development of gated materials using enzymes. In this proof-ofprinciple, the mesoporous material is capped with an active CDmodified-glucose oxidase (CD-GOx) through the formation of inclusion complexes between the cyclodextrins and the propylbenzymidazole group anchored to the solid support. In the presence of glucose as target substrate a cascade response results in a delivery of the entrapped cargo. In particular, CD-GOx converts glucose to gluconic acid which induces the protonation of benzimidazole which results in a dethreating of the inclusion complex and delivery of the dye. The approach is simple and versatile and may allow to inspire the design of high selective oncommand delivery systems based on enzyme's activity on target substrates for different applications.

Financial support from the Spanish Government (projects MAT2012-38429-C04-01 and CTQ2011-24355), Generalitat Valenciana (project PROMETEO/2009/016), UPV (project SP20120795) and Ramón y Cajal Programme (to R.V.) is gratefully acknowledged.

\section{References}

1 a) C. Coll, A. Bernardos, Martínez-Máñez, F. Sancenón, Acc. Chem. Res. 2013, 46, 339; b)E. Aznar, R. Martínez-Máñez, F. Sancenón, Expert Opin. Drug Deliv. 2009, 6, 643; c) K. Cotí, M. E. Belowich, M. Liong, M. W. Ambrogio, Y. A. Lau, H. A. Khatib, J. I. Zink, N. M. Khashab, J. F. Stoddart, Nanoscale, 2009, 1, 16.

2 C. T. Kresge, M. E. Leonowicz, W. J. Roth, J. C. Vartuli, J. S. Beck, Nature 1992, 359, 710.

3 See for example: a) C.-Y Lai, B.G. Trewyn, D.M. Jeftinija, K. Jeftinija, S. Xu, S. Jeftinija, V. S. -Y. Lin, J. Am. Chem. Soc. 2003, 125, 4451; b) C. Park, K. Oh, S.C. Lee, C. Kim, Angew. Chem. Int. Ed. 2007, 46, 1455; c) R. Casasús, E. Climent, M.D. Marcos, R. Martínez-Máñez, F. Sancenón, J. Soto, P. Amorós, J. Cano, E. Ruiz, J. Am. Chem. Soc. 2008, 130, 1903; d) R. Liu, P. Liao, J. Liu, P. Feng, P. Langmuir 2011, 27, 3095; e) E. Climent, R. MartínezMáñez, F. Sancenón, M. D. Marcos, J. Soto, A. Maquieira, P. Amorós, Angew. Chem. Int. Ed. 2010, 49, 7281.

4 a) N. K. Mal, M. Fujiwara, Y. Tanaka, Nature 2003, 421, 350; b) Q. Fu, G. V. R. Rao, L. K. Ista, Y. Wu, B. P. Andrzejewski, L. A. Sklar, T. L. Ward, G. P. López, Adv. Mater. 2003, 15, 1262; d) E. Aznar, L. Mondragón, J.V. Ros-Lis, F. Sancenón, M.D. Marcos, R. Martínez-Máñez, J. Soto, E. Pérez-Payá, P. Amorós, Angew. Chem. Int. Ed. 2011, 50, 11172; e) E. Bringas, Ö. Köysüren, D. Quach, M Mahmoudi, E. Aznar, J.D. Roehling, M.D. Marcos, R. MartínezMáñez, P. Stroeve, Chem. Comm. 2012, 48, 5647.

5 See for example: (a) K. Patel, S. Angelos, W. R. Dichtel, A. Coskun, Y.-W. Yang, J. I. Zink, J. F. Stoddart, J. Am. Chem. Soc., 2008, 130, 2382; (b) A. Schlossbauer, J. Kecht, J. Bein, Angew. Chem., Int. Ed., 2009, 48, 3092; (c) C. Park, H. Kim, S. Kim and C. Kim, J. Am. Chem. Soc., 2009, 131, 16614; (d) A. Bernardos, L. Mondragon, E. Aznar, M.D. Marcos, R.Martínez-Máñez, F. Sancenón, J. Soto, J.M. Barat, E. Pérez-Payá, C. Guillem, P. Amorós, ACS Nano, 2010, 4, 6353; (e) A. Agostini, L. Mondragón, A. Bernardos, R. Martínez-Máñez, M.D. Marcos, F. Sancenón, J. Soto, A. Costero, C. Manguan-García, R. Perona, M. MorenoTorres, R. Aparicio-Sanchis, J.R. Murguía, Angew. Chem. Int. Ed. 2012, 51, 10556; (f) E. Climent, E. Martínez-Máñez, F. Sancenón, M. D. Marcos, J. Soto, A. Maquieira, P. Amorós, Angew. Chem. Int. Ed. 2010, 49, 7281; (g) A. Schlossbauer, S. Warncke, P.M.E. Gramlich, J. Kecht, A. Manetto, T. Carell, T. Bein, Angew. Chem. Int. Ed. 2010, 49, 4734 (h) E. Climent, A. Bernardos, R. MartínezMáñez, A. Maquieira, M. D. Marcos, N. Pastor- Navarro, R. Puchades, F. Sancenón, J. Soto, P. Amorós, J. Am. Chem. Soc. 2009, 131, 14075.

6 Y.Zhao, B.G. Trewyn, I.I. Slowing, V.S.Y. Lin, J. Am. Chem. Soc. 2009, 131, 8398.

7 M. Holzinger, L. Bouffier, R. Villalonga, S. Cosnier, Biosensors and Bioelectronics 2009, 24, 1128.

8 a) N. S. Oliver, C. Toumazou, A. E. G. Cass and D. G. Johnston, Diabetic Medicine, 2009, 26, 197; b) Q. Wu, L. Wang, H. Yu, J. Wang, Z. Chen, Chem. Rev. 2011, 111, 7855.

9 a) Y. Xu, P.E. Pehrsson, L. Chen, R. Zhang, W. Zhao, J. Phys. Chem. C, 2007, 111, 8638; b) C. Song, P.E. Pehrsson, W. Zhao, J. Mater. Res. 2006, 21, 2817; c) R. Badugu, J.R. Lakowicz, C.D. Geddes, Anal. Chem., 2004, 76, 610. 